УДК 786.2: 78.071.1(477)"20

DOI: https://doi.org/10.33643/kmus.2019.58.03

\author{
Анастасія Шаріна, \\ аспірантка кафедри теорії музики \\ Національної музичної академї України ім. П. І. Чайковського \\ https://orcid.org/0000-0002-1538-3740 \\ anastasia13conpassione@gmail.com
}

Anastasiia Sharina,

Postgraduate at the Theory of Music Department, Ukrainian National Tchaikovsky Academy of Music https://orcid.org/0000-0002-1538-3740 anastasia13conpassione@gmail.com

\title{
«РОЗШИРЕНІ» СПОСОБИ ФОРТЕПІАННОГО ЗВУКОВИДОБУВАННЯ: ДОСВІД КЛАСИФІКАЦІї \\ (на прикладі творів для фортепіано соло сучасних українських композиторів)
}

Актуальність статmі обумовлюється необхідністю дослідження «розширених» способів фортепіанного звуковидобування в творчості сучасних українських композиторів. ІЇ̈ метою є розгляд «розширених» способів гри на фортепіано та класифікація принципів їх реалізації в творах. Методологічною базою дослідження $є$ методи системного, історичного та виконавського аналізу. Головні результати. Сучасні українські композитори активно застосовують нові способи гри на фортепіано, що виявляється в їхньому творчому доробку. Досліджені у статті композиції є прикладами звернення їх авторів до різних жанрів та образних сфер та спрямовані на пошук нового слухового й емоційного досвіду.

Ключові слова: «розширені» способи гри на фортепіано, українські сучасні композитори, твори для фортепіано соло, класифікація.

Sharina Anastasiia. Extended piano techniques: the experience of classification (at the examples of Ukrainian composers' works for piano solo). The relevance of the study is due to the fact that today there is no fundamental scientific study which is devoted to research the extended methods of piano playing in the works of contemporary Ukrainian composers. Also, still there is an open question which is going to establish the causes and the neediness for the using extended ways of piano sound in the works of Ukrainian composers of the second half of the $20^{\text {th }}$ - beginning of the $21^{\text {st }}$ century. The main objectives of the study are to consider the extended methods of piano 
playing and create classification of the principles for their implementation in musical works. The methodological bases of the research are the methods of historical, system and performing analysis, which are aimed at the in-depth study of the scientific literature which is devoted to the issue, interested us and the analysis of the musical creativity of Ukrainian authors. The scientific novelty of the research lies in the fact that attention to extended piano techniques in the works of contemporary Ukrainian composers is paid for the first time. Also, extremely new phenomenon becomes the systematization of works for piano solo by Ukrainian contemporary composers, from the standpoint of using extended piano methods of playing the piano in their musical heritage. Conclusions. An important innovation of the $20^{\text {th }}$ century is the introduction extended performing techniques. Contemporary European and American authors as well as composers of the post-Soviet countries are actively demonstrating their position in the formation of a completely new vision: using extraordinary methods of playing instruments. The analysis of works for piano solo by Ukrainian composers of the second half of the $20^{\text {th }}$ - beginning of the $21^{\text {st }}$ century demonstrates their creative achievement by many genres, various imaginative areas that convey the character of the works which are aimed at discovering new emotional areas, as well as acquiring a fundamentally new listening experience. The article proposes a classification of works for piano solo, which composed using extended ways of playing. Works by Ukrainian contemporary composers are systematized at three attributes: the number of techniques, the degree of use, the number of performers.

Key words: «extended» techniques of playing piano, Ukrainian contemporary composers, works for piano solo, classification.

Шарина Анастасия. «Расширенные» способы фортепианного звукоизвлечения: опыт классификации (на примере произведений для фортепиано соло современных украинских композиторов). Актуальность статьи обусловлена тем, что на сегодняшний день вопросу исследования «расширенных» способов игры на фортепиано в творчестве современных украинских композиторов не посвящено ни одного фундаментального исследования. Также на данный момент открытым вопросом является установление причин и необходимости применения «расширенных» способов фортепианного звукоизвлечения в произведениях украинских композиторов второй половины $\mathrm{XX}$ - начала XXI веков. Целью статьи является рассмотрение «расширенных» способов фортепианного звукоизвлечения и классификация принципов их реализации в музыкальных произведениях. Методологической базой исследования являются методы системного, исторического и 
исполнительского анализа, которые нацелены на углубленное изучение научной литературы, посвященной интересующему нас вопросу и анализу музыкального творчества украинских авторов. Научная новизна исследования заключается в том, что впервые внимание уделяется «расширенным» способам фортепианного звукоизвлечения в творчестве современных украинских композиторов; сделана систематизация произведений для фортепиано соло украинских композиторов второй половины XX-начала XXI столетий с позиции использования в них «расширенных» способов игры на фортепиано. Выводы. Важнейшей новацией XX столетия явилось введение «расширенных» способов игры на музыкальных инструментах. Современные европейские, американские композиторы, а также композиторы постсоветских стран активно демонстрируют свою позицию в формировании совершенно нового подхода в применении методов игры на инструментах. Исследование произведений для фортепиано соло украинских композиторов второй половины XX - начала XXI веков демонстрирует творческое освоение ими многих жанров, различных образных сфер, которые передают характер произведений и нацелены на расширение эмоциональной палитры, а также приобретение принципиально нового слушательского опыта. В статье предложена классификация произведений для фортепиано соло, написанных с использованием «расширенных» способов игры. Сочинения систематизированы по трем признакам: по количеству приёмов, по частоте их использования, по количеству исполнителей.

Ключевые слова: «расширенные» способы игры на фортепиано, украинские современные композиторы, произведения для фортепиано соло, классификация.

Актуальність даної статmі зумовлена тим, що на сьогоднішній день питанню дослідження «розширених» способів гри на фортепіано в творчості сучасних українських композиторів не присвячено жодного фундаментального дослідження. Також на даний момент відкритою залишається проблема осягнення причин та необхідності втілення «розширених» способів фортепіанного звуковидобування у творах українських композиторів другої половини XX - початку XXI століть.

Наукова новизна дослідження полягає в тому, що вперше увага приділяється «розширеним» способам гри на фортепіано у творчості сучасних українських композиторів; систематизовано твори для фортепіано соло українських композиторів другої половини XX - початку XXI століть 
3 позиції застосування в них «розширених» способів фортепіанного звуковидобування.

Mema cmammi полягає в розгляді «розширених» способів фортепіанного звуковидобування та класифікації принципів їх реалізації в творах українських композиторів другої половини XX - початку XXI сторіч.

Поставлена мета зумовила такі завдання дослідження:

- надати визначення феномену «розширених» способів гри на музичних інструментах;

- висвітлити основні прийоми гри на фортепіано, що входять у систему «розширених» методів звуковидобування;

- систематизувати «розширені» способи гри на фортепіано за технікою виконання;

- надати загальну характеристику творам для фортепіано соло 3 застосуванням «розширених» способів фортепіанного звуковидобування в сучасній українській музиці, зробити їх класифікацію.

Методологічною базою роботи є методи системного, історичного та виконавського аналізу, за допомогою яких вироблено класифікацію творів iз застосуванням «розширених» способів звуковидобування в творчості сучасних українських композиторів.

Результати дослідження. Здавна музика була спрямована на вираження певних емоційних станів. Ліричні й драматичні образи підкреслювала мінорна тональність, галантність виявляла себе в танці, стан піднесення втілювався в хоровому співі тощо. Навіть зараз, через століття, музика є незмінною сферою справдження різноманітних образів, явних чи зашифрованих послань. Відмінними є лише відчуття людей, зокрема композиторів й виконавців, що живуть на планеті Земля. Стикаючись iз новою реальністю сьогодення, вони знаходять та випробовують нові шляхи звукового зображення дійсності.

Відтепер шум міста, машин, побутових пристроїв є музичним елементом звуком. Орієнтиром пошуку стають незвичні засоби виразності, які найяскравіше можуть відтворити процес трансформації мислення людства та стрімкий науково-технічний прогрес.

Музика Новітнього часу підлягає переосмисленню: змінюється уявлення про іiі сутність, 3'являються нові жанри, форми презентації, композиторські техніки. У першій половині ХХ століття застосовується препарація, мікротонові співзвучності; створюються екзотичні інструменти: телармоніум, хвилі Мартено, терменвокс тощо. 
3 появою у XX столітті Першої, а згодом і Другої хвилі авангарду, докорінно трансформується уявлення композиторів про типовість та традиційність способів звуковидобування, а отже i специфіку гри на музичних інструментах. З'являється необхідність радикальних змін у звучанні інструментів, щоби віднайти якомога більше якісно нових тембрів, котрі відповідали б новаціям науково-технічного прогресу та революційним змінам у світосприйнятті людей.

До початку XX століття кожен музичний інструмент розглядався митцями, виконавцями та слухачами 3 позиції властивої лише йому тембрової палітри звучання. Також, усталені традиції звуковидобування на інструментах сформували загальне сприйняття функціонального навантаження кожного «класичного» способу гри. Це означало, що швидкі пасажі, гучні акорди, певні гармонічні звороти виявляли чітку сферу їх використання та впроваджувалися з конкретною метою.

Бачимо, що вже на початку XX століття фортепіано виступає перед нами в іншому амплуа. Відбуваються експерименти з використанням нових можливостей його звучання. Раніше інструмент розглядався композиторами та виконавцями з позиції його ударно-клавішної специфіки, що зумовлено, в першу чергу, самою ідеєю створення фортепіано молоточок, що вдаряє о струну. На початку XX століття центр уваги зміщується на саме джерело появи звуку - струни фортепіано.

Серед новацій XX сторіччя значущою подією в професійному житті музикантів стало введення extended techniques («розширені техніки»). Цей термін науковці визначають як набір методів, що використовуються в музиці з метою реалізації нетрадиційних або «неправильних» звучань у співі або грі на музичних інструментах.

Американський піаніст та дослідник «розширеного» фортепіано Л. Ваес визначає «неправильне» застосування інструмента, зокрема фортепіано, наступним чином: «<... “розширений” інструмент ніщо ані більш, ані менш, ніж нетипове використання його властивостей. У випадку 3 “розширеним" фортепіано: неординарними $є$ саме такі техніки, що не використовують вертикальну артикуляцію пальцем на клавіші<...>» $[9$, c. 978]. Можемо додати, що окрім цього, «розширеними» способами гри на фортепіано вважаються такі, що виходять за межі використання лише клавіатури інструмента, внаслідок чого відбувається збагачення колористичної палітри інструмента.

Шляхом «розширеного» фортепіано пішло багато композиторів. Наприклад, Джордж Крам (1929 р. н.) у циклі «Макрокосмос» для фортепіано соло поєднує традиційні методи звуковидобування 3 
нестандартними способами гри на фортепіано, які притаманні струнним, ударним інструментам та голосу. Софія Губайдуліна (1931 р. н.) у першій частині Сонати для фортепіано окрім звичних прийомів гри використовує глісандо бамбуковою паличкою на струнах, кластер на клавішах, затискання певних струн лівою рукою в момент гри на клавіатурі правою (silently depressed keys). Подібних творів у фортепіанній літературі другої половини XX - початку XXI сторіч можна знайти величезну кількість.

Серед найяскравіших композиторів, котрі активно працювали в цьому напрямку, можемо назвати імена Генрі Кауелла, Джона Кейджа, Джорджа Крама, Дьордя Лігеті, Дьордя Куртага, Лучано Беріо, П'єра Булеза, Мауріціо Кагеля, Софії Губайдуліної, Карлгайнца Штокгаузена, Гельмута Лахенмана та багатьох інших.

Відомо, що «розширені техніки» гри на фортепіано з`явилися на початку XX століття в Сполучених Штатах. Винахідником цього напрямку вважається лідер американського музичного «ультрамодернізму», композитор, піаніст, теоретик й дослідник музики Генрі Кауелл (1897-1965), котрий досліджував феномен «нового звучання» та використав «розширені» способи гри у своїх творах.

Кауелл відкрив для себе музику афро-кубинської традиції, культуру мексиканських аборигенів, жителів Таїті й Індонезії, японську та індійську традиційну музику. Композитор розвивав ідею нової «ритмогармонії», основаної на «тон-кластерах», та відобразив це в перших фортепіанних опусах. Неординарне, часто грубо-ударне трактування фортепіано, зокрема, гра кулаком, ліктем, долонею на клавіатурі та струнах рояля, сформували фірмовий стиль молодого автора. Серед найвідоміших творів Кауелла - «The Tides of Manaunaun» (1912), «Aeolian Harp for string piano» (1923), «The Banshee for string piano» (1925) та «Sinister Resonance for string piano» (1930).

Г. Кауелл запропонував незвичні для того часу способи звуковидобування. Подібне використання інструмента за часів новатора отримало назву «струнне фортепіано», що означало виконання всередині рояля. Композитор надихнув до експериментів зі звучанням свого учня, відомого американського музичного експериментатора Джона Кейджа (1912-1992), котрий продовжив пошуки вчителя та створив підготовлений рояль (prepared piano).

Порівнюючи «розширене» фортепіано з препарованим, що у 1938 році винайшов Кейдж, можемо зазначити, що жодних змін в конструкції або внутрішньому наповненні «розширеного» інструмента не відбувається.

На нашу думку, переклад англійського терміну «extended techniques» українською як «розширені техніки» є дещо незрозумілим та зашироким 
визначенням. Щоб уникнути калькування в перекладі, пропонуємо дієприкметник «розширений» взяти у лапки та використовувати поняття «спосіб», як синонім до «методу» гри, завдяки якому відбувається відтворення «неправильних» звучань на музичних інструментах.

Отже, «розширені» способи фортепіанного звуковидобування давно вкоренилися в композиторській творчості. Ця тема висвітлюється насамперед у працях американських, європейських і російських науковців. Так, наприклад, у «Педагогічному путівнику до розширених фортепіанних технік» Жана-Франсуа Проулкса [6] зазначено наступні види «розширених технік»: cluster на клавіатурі, glissando на струнах, pizzicato на струнах, mute струн, harmonics. Ішія Рейко у праці «Розвиток розширених фортепіанних технік в американській музиці XX століття» [7] зазначає, що cluster на клавіатурі, silently depressed keys (беззвучно натиснуті клавіші), plucking (щипок), striking (удар), stroking (погладжування вздовж) струни, glissandi на струнах, tremolo струн, muting (затискання) струн та harmonics входять в систему extended piano techniques та активно використовуються композиторами. Люк Ваес у дисертації «Розширені фортепіанні техніки в теорії, історії та виконавській практиці» [9] до «розширених» способів гри відносить: glissando на струнах та клавішах, cluster на струнах та клавіатурі, pizzicato на струнах та mute.

Бачимо, що кількість вищеназваних способів звуковидобування досить велика. Майже всі вони викликають асоціативний зв'язок і приблизне розуміння семантичних і теоретичних засад їх використання. У подальшому викладі запропоновано базові тлумачення вказаних способів фортепіанного звуковидобування, що узагальнюють різноманітні першоджерела.

У європейській, американській та українській сучасній музиці найрозповсюдженішими 3 нестандартних способів фортепіанного звуковидобування є: glissando, cluster, pizzicato, mute, silently depressed keys, tremolo струн, knocking дерев'яних поверхонь фортепіано.

Перелік Люка Ваеса $є$ найбільш лаконічним та майже повністю відповідає кількості популярних способів фортепіанного звуковидобування у творах композиторів другої половини XX - початку XXI століть. Окрім цього, було досліджено, що способи, котрі входять до списку Л. Ваеса, є найважливішими, насамперед, для музики українських авторів.

Отже, спираючись на класифікацію американського дослідника, були знайдені, опрацьовані, перекладені та оформлені в більш лаконічному вигляді наступні тлумачення «розширених» способів гри, що проілюстровані на прикладах творів для фортепіано соло сучасних українських композиторів. 
«Глісандо (італ. glissando, від франц. glisser - ковзати) - виконавський прийом гри на музичних інструментах. Полягає в легкому ковзанні пальця вздовж грифу струнних інструментів (смичкових або щипкових), швидкому проведенні пальцем однієї або обох рук на струнах арфо- і ліроподібних інструментів <..>, на фортепіано - у ковзанні одного чи декількох пальців переважно на білих клавішах» [9, с. 139]. Глісандо може виконуватись як на клавіатурі, так і на струнах фортепіано, тому використання цього способу звуковидобування у творах є досить вживаним. На нашу думку, це обумовлено рясністю звукових відтінків, що утворюються завдяки застосуванню глісандо як на клавіатурі, так і на струнах. Окрім цього, його виконання на сцені під час концерту виглядає надзвичайно ефектно. Наприклад, глісандо на клавіатурі використала А. Корсун у п’єсі «Aqua Sonare» для фортепіано соло (2008). Глісандо на струнах фортепіано знаходимо у творі В. Кияниці «Три клавірштюки в реальному часі» для фортепіано соло (2011).

Кластер (англ. cluster - гроно, скупчення), - за визначенням Г. Кауелла, - «співзвуччя, утворене щільним скупченням малих або великих секунд, що є обов'язковою умовою трактування цього скупчення» [1]. Кластер, так само, як і глісандо, використовується на клавішах і струнах інструмента. Його реалізація відбувається, переважно, завдяки горизонтальному положенню пальців, долоні або передпліччя. Застосування кластера є напрочуд популярним. Це зумовлено тим, що велика кількість звуків натиснутих одночасно на клавішах або взятих долонею на струнах, мають достатньо широкий динамічний нюанс, отже можуть втілювати найрізноманітніші задуми композитора лише завдяки використанню одного способу звуковидобування. Наприклад, кластер на клавішах застосував В. Рунчак у творі «Привіт М.К. трьохСУчасна сонаРна N'орма» для фортепіано в трьох частинах (2001). Кластер на струнах використав I. Щербаков у Сонаті № 2 для фортепіано соло (Романтична елегія для домашнього музикування) «Коли втомлене серце...» (1994).

«Піцикато (від італ. pizzicato - щипком) - спосіб гри на смичкових музичних інструментах, що зумовлює видобування звуку не смичком, а щипком пальця» [4]. Піцикато, на противагу глісандо та кластеру, застосовується лише на струнах фортепіано. Звичайно, це пов'язано 3 самою природою механізму інструмента, його будовою. Піцикато ж, як спосіб звуковидобування, був запозичений у струнного сімейства. Характерною рисою виконання pizzicato, на відміну від glissando, cluster та mute, є залучення лише вертикальної позиції пальця. Саме це увиразнює його серед інших «розширених» способів звуковидобування. Наприклад, «Гласс-елегія» для фортепіано: 8' Л. Юріної (1998). 
«Мьют (англ. тите - сурдина, надягати сурдину)» [3] - беззвучне затискання струн або клавіш. «Природно, затискання відбувається завдяки пальцям однієї з рук, що блокують певні струни, а саме, їх вібрації» [6, c. 49]. Техніка виконання прийому, на нашу думку, була запозичена 3 гітарної гри. На сьогоднішній день, досліджені нами роботи американських та європейських науковців пропонують застосування терміну тиtе лише до струн фортепіано, а для блокування клавіш вони застосовують термін silently depressed keys. На нашу думку, доречним є тлумачення mute у зв'язку з обома способами звуковидобування, як з грою на струнах, так i звуковидобуванням на клавішах інструмента. Новаторський підхід виконання mute на фортепіано базується на ідеї поєднання одночасної гри на струнах та клавішах рояля. Таким чином, використання цього способу звуковидобування є можливим у трьох варіантах. Піаніст може:

1. затискати пальцями або долонею частину клавіатури фортепіано, одночасно граючи на притиснутих клавішах (ефект ударного звучання);

2. притискати клавіші рояля, одночасно граючи на струнах (ефект використання правої педалі);

3. затискати струни та синхронно грати на тих клавішах, за які відповідають блоковані струни (ефект гри піцикато).

Mute на клавішах й струнах використовується багатьма сучасними українськими композиторами. Наприклад, О. Безбородьком у «Intermezzo» для фортепіано (2011), В. Цаньком у Фортепіанній Сонаті №3 «AER» (2017).

Отже, спираючись на приклади творів сучасних українських композиторів, описані «розширені» прийоми фортепіанного звуковидобування за технікою виконання можемо віднести до трьох груп:

- на клавішах;

- на струнах;

- одночасне застосування струн та клавіатури інструмента.

До першої групи з висвітлених технік звуковидобування належать: glissando, cluster, mute. До другої- glissando, cluster, mute та pizzicato. Третя група включає в себе glissando, cluster, mute й pizzicato та є найбільш плодючою платформою для знаходження різноманітних тембрів, звуків, емоційних станів тощо.

«Розширені» способи фортепіанного звуковидобування $\epsilon$ дуже актуальними для українських композиторів, починаючи з другої половини ХХ століття. Більшість творів, у яких вони використовуються, $\epsilon$ ансамблевими. Відсоток композицій для фортепіано соло $є$ невеликим. Досліджено, що композиції для фортепіано соло, у яких використовуються 
«розширені» способи гри на фортепіано, мають переважно програмні назви i спрямовані, у своїй більшості, на створення певних звукозображальних ефектів.

Сучасні українські композитори використовують «розширені» способи гри на фортепіано в різноманітних жанрах. Серед них знаходимо такі визначення, як Концертна фантазія, Соната, П’єса, Клавірштюк, Інтермецо, Мазурка тощо.

За образними сферами переважають твори, що зображають: явища природи («Aqua Sonare», «AER»); емоційні стани («Dolcissima», «Euphoria»); алегоричні образи («Остання сутра», «Когда сейчас - это никогда», «Піна»); сатиричні образи («Одна мамка, сорок дідиків», «Ось так!»); містичні образи («Shadows and ghosts», «Сон Люцифера»).

Різноманітність жанрів та фантазійність представлених назв творів справді очевидна. Це спровокувало нас впорядкувати, систематизувати та спробувати виявити в творах для фортепіано соло певну закономірність використання «розширених» способів фортепіанного звуковидобування.

Таким чином, твори для фортепіано соло, де використано «розширені» способи гри, систематизуємо за трьома ознаками:

1. за кількістю прийомів:

- використання одного прийому (Клавірштюк № 3 Б. Кривопуста);

- використання сукупності прийомів («Shadows and ghosts» Л. Юріної);

2. за мірою використання:

- «розширені» способи гри застосовуються фрагментарно, переважають традиційні фортепіанні прийоми звуковидобування (Соната № 2 С. Луньова);

- традиційні та розширені прийоми звуковидобування задіяні композитором на рівних правах у відсотковому та функціональному співвідношенні («Піна» О. Шмурака);

- твори побудовані виключно на роботі 3 «розширеними» способами гри («Ось так!» С. Зажитька);

3. за кількістю виконавців:

- соліст («13 pieces» В. Кияниці);

- соліст та асистент («De(zember)» А. Кобзар).

Висновки. Авангардні способи гри мають відрізнятися від типових, звичних прийомів, тому досягнення небуденного звука відбуватиметься за допомогою залучення оригінальних методів звуковидобування. На нашу думку, «розширеними» способами гри можемо вважати саме такі, що були створені з метою реалізації нетрадиційних звучань на інструменті. Але яким чином «розширюються» способи гри на фортепіано? Створюючи 
фортепіано, його творці на вряд чи припускали, що кому-небудь спаде на думку використовувати не тільки клавіші, а й струни інструмента задля досягнення нетипових фортепіанних тембрів. Саме тому логіка митців спрацювала на користь залучення оригінальних методів гри, які допомагають віднайти якомога більше якісно нових тембрів, що відповідали б революційним змінам. Окрім застосування клавіатури фортепіано, увагу композиторів привертають до себе струни, педальний механізм, кришка, бокові деки тощо. Адже, використання «розширених» способів звуковидобування націлене на збагачення колористичної й тембрової палітри інструмента. Виявляється, добре знайоме нам класичне фортепіано попередніх епох ще може неабияк здивувати стомлене від одноманітної плинності піаністичних чорно-білих буднів вічне тріо «однодумців-співробітників»: композитора, виконавця та слухача. Дане дослідження присвячене творам для фортепіано соло, адже спроба «розширити» темброві можливості фортепіано, роблячи його самостійним і незалежним від інших інструментів, здається напрочуд цікавою. Таким чином, композитори можуть задіювати лише один, універсальний інструмент, який може змагатися за кількістю тембрів 3 цілим симфонічним оркестром.

1. Кластер [Электронный ресурс]// Музыкальный словарь: веб-сайт. URL: http://www.music-dic.ru/html-music-keld/k/3214.html (дата обращения: 26.01.2019).

2. Музыкальный энциклопедический словарь. Москва : Советская энциклопедия, 1991. $672 \mathrm{c}$.

3. Мьют [Электронный ресурс] // Словарь иностранных музыкальных терминов. URL: https://musical_terms.academic.ru/4720/mute (дата обращения: 27.01.2019).

4. Піцикато [Електронний ресурс] // Словник-довідник музичних термінів : за книгами Ю. Є. Юцевича. URL: http://term.in.ua/indeks.html?term=ПІЦИКАТО (дата звернення: 28.01.2019).

5. Хруст Н. Новые инструментальные техники. Опыт классификации // Научный вестник Московской консерватории. 2016. № 1 [24]. С. 125-143.

6. Proulx J.-F. A pedagogical guide to extended piano techniques : a monograph submitted to the Temple University graduate board in partial fulfillment of the requirements for the degree of Doctor of musical arts. Philadelphia : Temple University, 2009. 138 p.

7. Reiko I. The Development of extended piano techniques in twentieth-century American music: A Treatise submitted to the College of Music in partial fulfillment of the requirements for the degree of Doctor of Music. Tallahassee : Florida State University College of Music, 2005. $127 \mathrm{p}$.

8. Smith G. E. Performance Techniques for Four Avant-garde Piano Pieces by Henry Cowell : Honors Thesis. Berrien Springs (Michigan) : Andrews University, 2011.30 p.

9. Vaes L. Extended Piano Techniques in Theory, History and Performance Practice. Leiden : Leiden University, 2009. 1081 p. 


\section{References}

1. Cluster (1990). Muzykalnyi entsiklopedicheskiy slovar [online]. Moscow: Sovetskaya Encyclopediya. Available at: http://www.music-dic.ru/html-music-keld/k/3214.html [Accessed 26 Jan. 2019] [in Russian].

2. Musical Encyclopedic Dictionary. (1991). Moscow: Sovetskaya Encyclopediya [in Russian].

3. Mute. Slovar inostrannykh muzykalnykh terminov [online]. Available at: https://musical_terms.academic.ru/4720/mute [Accessed 27 Jan. 2019] [in Russian].

4. Yutsevych, Y. (2009). Pizzicato. Slovnyk-dovidnyk muzychnykh terminiv [online]. Available at: http://term.in.ua/indeks.html?term=ПІЦИКАТО [Accessed 28 Jan. 2019]. [in Ukrainian].

5. Khrust, N. (2016). New instrumental techniques. Classification experience. Nauchnyy vestnik Moskovskoy konservatorii, 1 (24), pp. 125-143 [in Russian].

6. Proulx, J.-F. (2009). A pedagogical guide to extended piano techniques. Doctor of Musical Arts thesis. Philadelphia: Temple University [in English].

7. Reiko, I. (2005). The Development of extended piano techniques in twentieth-century American music. Doctor of Music thesis. Tallahassee: Florida State University College of Music [in English].

8. Smith, G. E. (2011). Performance Techniques for Four Avant-garde Piano Pieces by Henry Cowell. $\mathrm{PhD}$ thesis. Berrien Springs: Andrews University [in English].

9. Vaes, L. (2009). Extended Piano Techniques in Theory, History and Performance Practice. PhD thesis. Leiden: Leiden University [in English].

УДК 784.3.071.1:82-1:781.62(477)

DOI: https://doi.org/10.33643/kmus.2019.58.04

Анна Калініна,

здобувач кафедри історії української та зарубіжної музики, старший лаборант навчальної лабораторії історії украӥнської та зарубіжной музики Харківського начіонального університету мистецтв імені І. П. Котляревського https://orcid.org/0000-0001-6938-4194 anet0692@ukr.net

Anna Kalinina, Applicant of the Department of History of Ukrainian and Foreign Music, Senior laboratory assistant at the educational laboratory of History of Ukrainian and Foreign Music, Kharkiv National I. P. Kotlyarevsky University of Arts https://orcid.org/0000-0001-6938-4194 anet0692@ukr.net

\section{СПІВВІДНОШЕННЯ МУЗИЧНОГО ТА ПОЕТИЧНОГО РИТМУ В РАННІХ ВОКАЛЬНИХ ЦИКЛАХ ВАЛЕНТИНА БІБІКА}

Розглядаються принципи втілення віршового ритму у трьох ранніх вокальних циклах В. Бібіка - «Пісні батьківського дому», «Акварелі» та 